مجلة كلية التربية بالإسماعيلية - العدد الثامن والثلاثون - مايو Y Y Y Y

\title{
EFFECTS OF BROCCOLI ON THE NUTRITIONAL STATUS OF DIABETIC RATES
}

Mohamed Sayed EIZoghbi ${ }_{1}$, Nefisa Hassan EIBanna 2 , Sawsan

Ahmed Mohamed Abed El-Ghany ${ }_{3}$, Dalia Wheed Ziedan 3

1 Prev. President of Suez Canal University

2 Department of Nutrition and Food Science, Faculty of Home Economics, Helwan University

3 Department of Home Economics, Faculty of Education, Suez Canal University

Abstract:

The present study was carried out to evaluate the effect of broccoli on the nutritional status of diabetic rats.

Background: Broccoli is a plant in the cabbage family, whose large flower head is used as a vegetable. Broccoli is a source of bioactive compounds such as phenolics, flavonoids and glucosinolates, which possess antioxidant and anticancer effects these compounds are used in the treatment of human diseases. They can quench free radicals, act as antiproliferative agents, promote detoxifying enzymes, induce differentiation of cancer cells, stimulate the immune system and inhibit tumor blood vessel formation. Also, the bioactive compound in broccoli sprouts was used for treatment diabetes.Therefore, the present study designed to assess the effect of broccoli on the nutritional status of diabetic rats. Objectives: the aim of this study was conducted to investigate the effect of broccoli on the nutritional status of diabetic rats through assessment of level of serum glucose, insulin, lipid profiles and some liver and kidney functions. Materials and Methods: Broccoli was washed and sliced into small pieces and oven-dried at $50^{\circ} \mathrm{C}$. Dried plants were crushed and bolted to get smooth powder. Diabetic rats groups were induced by injection of sterptozotocin (STZ) and they were fed on basal diet containing 2.5 and $5 \%$ Broccoli and the remaining groups were positive and negative control. After that the effect of the diet on the nutritional status, serum glucose, insulin, lipid profiles (TC, TG, LDL-C, HDL-C and VLDL-C), liver (ALT and AST) and kidney (creatinine, urea and uric acid) functions in the serum of rats were assessed. Also, histopathological changes were evaluated Results: It was found that broccoli has no significant differences toward body weight and food efficiency ratio of the all groups when compared with positive Control. Broccoli reduced the serum glucose level in the all groups. The group of 5\% broccoli showed the best response.Also, this group showed 
the most improvement in serum total cholesterol level. All groups have a reduction in serum triglycerides levels in this experiment. The group of $5 \%$ broccoli showed the best response. The mean values of serum LDL-C level decreased in the all groups, and all groups have a reduction in serum (VLDL-C) levels in this experiment, and it was observed that the group of $5 \%$ broccoli showed the best response. Broccoli increased (HDL-C) level in blood serum of rats in all groups, and high levels showed best responses. In kidney functions, broccoli had no effect on uric acid level and enhanced urea and creatinine levels. Also, they decreased the liver enzymes (AST and ALT). Conclusion: The present study concluded that broccoli have no effect on nutritional status but could enhance glucose levels, lipid profile, kidney and liver functions in blood serum of rats in the all groups. The most of best results showed in the high levels broccoli $(5 \%)$. Keywords: Broccoli, diabetes, lipid profiles, Blood glucose level, Insulin level, kidney and liver functions.

\section{Introduction:}

Broccoli is a plant in the cabbage family, whose large flower head is used as a vegetable. The word broccoli, from the Italian plural of broccolo, refers to "the flowering top of a cabbage". Broccoli is usually boiled or steamed, but may be eaten raw (Wien and Wurr, 1997). Broccoli contains many bioactive, including vitamins Cand $\mathbf{E}$, quercetin and kaempferol glycosides and, like other members of the Brassicaceae, several glucosinolates, including glucobrassicin (3indolylmethyl glucosinolate) and glucoraphanin (4methylsulphinylbutyl glucosinolate). A key bioactive component responsible for much of this activity may be sulforaphane (1isothiocyanato- 4-methylsulfinylbutane), a hydrolysis product of glucoraphanin. Sulforaphane not only upregulates a number of phase II detoxification enzymes involved in clearance of chemical carcinogens and reactive oxygen species, but has anti-tumorigenic properties, causing cell cycle arrest and apoptosis of cancer cells. (Jeffery and Araya, 2009). Sulforaphane also almost completely prevented diabetesinduced cardiac oxidative damage (Bai, et al., 2013).

\section{The aim of the study:}

The present study was carried out to evaluate the effect broccoli on the nutritional status of diabetic rats through determination of serum glucose, insulin, serum lipid profile, kidney functions and liver functions in white albino rats. 


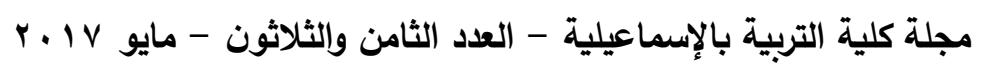

Materials and Methods:

Materials:

Rats:

Twenty four male albino rats of the Sprague Dawley strain weighting about $(150 \pm 10) \mathrm{g}$ were purchased from Vaccine and Immunity Organization, Helwan farm, Ministry of Health, Cairo, Egypt.

Broccoli:

Fresh broccoli (bro), was purchased from a local market

Basal diets:

The basal diet was prepared according to Reeves et al., (1993). Composition of mineral mixture prepared according to Hegested, (1941), Composition of Vitamin mixture prepared according to Kanapka, (1983).

\section{Methods:}

Preparation Broccoli:

Broccoli was washed and sliced into small pieces and oven-dried at $5^{\circ} \mathrm{C}$. Dried plants were crushed and bolted to get smooth powder.

Experimental diets and Design:

Rats were housed in cages in arrows maintained at $25+2^{\circ} \mathrm{C}$ and kept under normal healthy conditions. All rats fed on basal diets for $\mathbf{7}$ days before starting the experiment for adaptation. After one week period, all rats were divided into two main groups:

The First group (control negative) : This group (6 rats) fed on basal diet for 4 weeks and were only injected with citrate buffer.

The Second group: This group (18 rats) diabetes group was induced by injection of a single intraperitoneal dose of STZ (freshly prepared by using $0.01 \mathrm{M}$ citrate buffer, $\mathrm{pH}$ 4.5) as described by (Yanardag, et al., 2003). Diabetes was identified by 3 measuring blood glucose concentration $72 \mathrm{~h}$ after injection of STZ. Rats with a fasting blood glucose level above $150 \mathrm{mg} / \mathrm{dl}$ were considered diabetic and were used in this study.

The second group of rats was divided into 3 subgroups as follow: Group (2): Control positive: This group was fed on basal diet for 4 weeks.

Group (3): This group was fed on basal diet plus broccoli $2.5 \%$ (25gm/kg diet). Group (4): This group was fed on basal diet plus broccoli $5 \%(50 \mathrm{gm} / \mathrm{kg}$ diet). 
All groups were fed on last basal diet for 4 weeks.

Determination of body weight gain, food intake and relative organs weight:

The duration of the study was four weeks, Rats were weighted weekly and food intake was recorded daily during the experimental period. At the end of the experiment, body weight gain (BWG) and food efficiency ratio (FER) were determined according to the method of Chapman et al., (1959), using the following formulas:

BWG $=$ Final weight - Initial weight

Daily BWG $=\frac{\text { Final weight }- \text { Initial weight }}{28(\text { day })}$
FER $=$

Food intake (g)/day

The rats were anaesthetized by diethyl ether and sacrificed, Blood samples were collected into clean dry centrifuge tubes and were left at room temperature until the clot was formed; the blood was centrifuged for 10 minutes at 3000 r.p.m. to separate the serum. Serum was carefully aspirated and collected into clean plastic tubes and stored frozen at $-20^{\circ} \mathrm{C}$ until analysis.

Serum analysis:

Determination of Serum Insulin:

Serum Insulin was determined according to the method of (Temple et al., 1992).

Determination of serum glucose:

Enzymatic determination of serum glucose was carried out calorimetrically according to the method of Trinder (1969)

Determination of total cholesterol:

Total cholesterol was determined according to the method of (Burtis and Ashwood, 2001).

Determination of Triglycerides: 


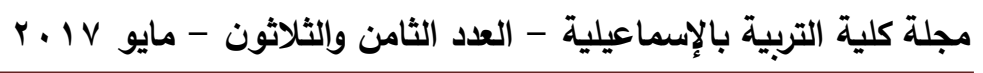

Triglycerides (TG) were determined according to the method of (Fossati and principe, 1982) and (McGowan et al., 1983).

Determination of HDL cholesterol:

The determination of high density lipoprotein cholesterol (HDL-C) was carried out according to the method of (Burtis and Ashood, 1999).

Determination of VLDL cholesterol:

The determination of very low density lipoprotein cholesterol (VLDLC) was carried out according to the method of Friedwald, et al. (1972) as the following: VLDL-C = Triglycerides $/ 5$.

Determination of LDL cholesterol:

Low- density lipoprotein cholesterol (LDL- C) was calculated according to the equation of Friedwald, et al. (1972) as the following:

LDL-C = Total cholesterol - (HDL-C + VLDL-C).

Determination of creatinine:

Creatinine was determined according to (Jaffé, 1986).

Determination of Urea:

Urea was determined according to (Villanova, 1994).

Determination of Uric acid:

Uric acid was determined according to (Schultz, 1984) and (Fossati et al., 1980)

Determination of serum aspartate amino transferase (AST):

Aspartate amino transferase (AST), this assay follows the (IFCC, 1980) method.

Determination of serum alanine amino transferase (ALT):

Alanine amino transferase (ALT), this assay follows the (IFCC, 1980) method.

Statistical analysis:

Data analyzed by SPSS version 18 statistical packages (SPSS Inc, Chicago, $I L$ ). Data are expressed as mean \pm Standard Deviation (mean \pm SD). One way analysis of variance $(F$ - test) used for comparison of the mean of more than two groups followed by LSD post-host. Test for multiple parawise comparisons between two groups, (T-test) used for comparing the mean of two groups.

Results and Discussion:

1-Effect of experimental diets on body weight gain (BWG) and food efficiency ratio (FER): 
Table (1) showed that the values of initial body weight, final body weight, daily body weight gain, daily food intake, body weight gain and food efficiency ratio. All animals under the present work show gain in the daily body weight The results indicated significant decrease in body weight gain and food efficiency ratio of the control positive (diabetic group: G2) as compared with the negative control (non diabetic group: G1). The mean values of body weight gain (BWG) were 16.67 \pm 4.57 and $13.00 \pm 1.32$, while food efficiency ratio (FER) were $0.044 \pm 0.012$ and $0.034 \pm 0.003$ respectively.

Table (1): Effect of experimental diets on body weight gain and food efficiency ratio of rats

\begin{tabular}{|c|c|c|c|c|c|c|}
\hline Gkoups & $\begin{array}{c}\text { Initial } \\
\text { body } \\
\text { weight } \\
\text { (g) }\end{array}$ & $\begin{array}{c}\text { Final } \\
\text { body } \\
\text { weight (g) }\end{array}$ & $\begin{array}{c}\text { Daily } \\
\text { body } \\
\text { weight } \\
\text { gain (g) }\end{array}$ & $\begin{array}{c}\text { Daily } \\
\text { food } \\
\text { intake } \\
\text { g/days }\end{array}$ & $\begin{array}{c}\text { body } \\
\text { weight } \\
\text { gain (g) }\end{array}$ & $\begin{array}{c}\text { Food } \\
\text { efficiency } \\
\text { ratio }\end{array}$ \\
\hline $\begin{array}{l}\text { G1(control } \\
\text { negative) }\end{array}$ & $\begin{array}{r}166.33 \\
\pm 4.42 \mathrm{a}\end{array}$ & $183.00 \pm 4.83$ & $0.59 \pm 0.16$ & $13.8 \pm 1.61$ & $16.67 \pm 4.57$ & $0.044 \pm 0.012$ \\
\hline $\begin{array}{c}\text { G2 (control } \\
\text { positive) }\end{array}$ & $\begin{array}{r}164.33 \\
\pm 2.43 \mathrm{a}\end{array}$ & $177.33 \pm 2.08$ & $0.46 \pm 0.47$ & $13.5 \pm 1.49$ & $13.00 \pm 1.32$ & $0.034 \pm 0.003$ \\
\hline $\begin{array}{r}\text { G7 }(2.5 \% \\
\text { Bro } \\
)\end{array}$ & $\begin{array}{l}150.67 \\
\pm 6.18\end{array}$ & $165.33 \pm 7.39$ & $0.52 \pm 0.13$ & $14.6 \pm 1.49$ & $14.67 \pm 3.55$ & $0.036 \pm 0.009$ \\
\hline $\begin{aligned} \text { G8 (5\% } & \\
& \text { Bro } \\
& \end{aligned}$ & $\begin{array}{r}165.00 \\
\pm 0.97^{\circ}\end{array}$ & $178.67 \pm 3.11$ & $0.49 \pm 0.098$ & $14.8 \pm 1.65$ & $13.67 \pm 2.74$ & $0.033 \pm 0.007$ \\
\hline
\end{tabular}

- Values are expressed as means $\pm \mathrm{SE}$.

- Means with the different letter superscripts in the same column denote significance at $P<0.05$.

\section{2-Effect of experimental diets on blood glucose level and insulin level:}

Blood glucose level:

Table (2) illustrate the mean + SE values of serum glucose level $(\mathrm{mg} / \mathrm{dl})$.The results in table (2) indicate that blood glucose level have 


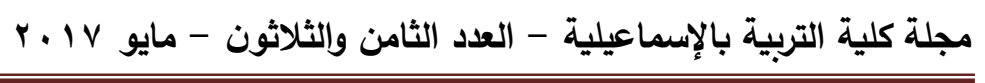

significant decrease in negative control G1, $(85.66 \pm 2.5 \mathrm{mg} / \mathrm{dl})$ when compared with positive control $\mathrm{G} 2,(152.0 \pm 3.0 \mathrm{mg} / \mathrm{dl})$.

The all groups have significant differences in the mean values of blood glucose level when compared with negative control G1, $(85.66 \pm 2.5$ $\mathrm{mg} / \mathrm{dl}$ ) and have significant differences when compared with positive control G2 $(152.0 \pm 3.0 \mathrm{mg} / \mathrm{dl})$. Also have significant differences in the mean values of blood glucose level among themselves.

The results in the current study are in agreement with Cho et al., (2006) and Kataya and Hamza (2008) who reported that STZ injections increased fasting blood glucose concentrations.

The results also in harmony with Cho et al., (2006) who found that broccoli led to significant decreases in serum glucose in diabetic rat.

Also the results similar Bahadoran et al., (2012) who showed that broccoli significantly decreased blood glucose level in human.

\section{Insulin level:}

Table (2) illustrate the mean $+\mathrm{SE}$ values of insulin level (IU/dl).The results in table (2) indicate that insulin level have significant increase in negative control G1, $(4.29 \pm 0.29 \mathrm{IU} / \mathrm{dl})$ when compared with positive control G2, (2.48 $\pm 0.19 \mathrm{IU} / \mathrm{dl})$.

The groups of broccoli $2.5 \%$ and $5 \%$ are $\mathbf{G 3}$ and $\mathrm{G} 4$ registered $2.71 \pm$ $0.086 \mathrm{IU} / \mathrm{dl}$ and $2.98 \pm 0.11 \mathrm{IU} / \mathrm{dl}$ respectively have significant differences in the mean values of insulin when compared with negative control G1, (4.29 $\pm 0.29 \mathrm{IU} / \mathrm{dl})$. But these groups (G3 and G4) have no significant differences in the mean values of insulin when compared with positive control G2, $(2.48 \pm 0.19 \mathrm{IU} / \mathrm{dl})$. There were no significant differences in the mean values of insulin among these groups (G3 and G4). 
Table (2): Effect of experimental diets on blood glucose level and insulin level:

\begin{tabular}{|l|c|c|}
\hline $\begin{array}{c}\text { Parameters } \\
\text { Groups }\end{array}$ & $\begin{array}{c}\text { Glucose } \\
\mathrm{mg} / \mathrm{dl}\end{array}$ & $\begin{array}{c}\text { Insulin } \\
\text { IU } / \mathrm{dl}\end{array}$ \\
\hline control negative & $\mathbf{8 5 . 6 6} \pm 2.5^{\mathrm{f}}$ & $4.29 \pm 0.18^{\mathrm{a}}$ \\
\hline control positive & $152.00 \pm 3.0^{\mathrm{a}}$ & $2.48 \pm 0.28^{\mathrm{cb}}$ \\
\hline $2.5 \%$ broccoli. & $124.83 \pm 1.4^{\mathrm{b}}$ & $2.71 \pm 0.086^{\mathrm{cb}}$ \\
\hline $5 \%$ broccoli. & $109.66 \pm 3.07^{\mathrm{cd}}$ & $\mathbf{2 . 9 8} \pm 0.11^{\mathrm{b}}$ \\
\hline
\end{tabular}

- Values are expressed as means $\pm \mathrm{SE}$.

- Means with the different letter superscripts in the same column denote significance at $P<0.05$

\section{r-Effect of experimental diets on lipid profile:}

\section{Total cholesterol (TC):}

Table (3) illustrate the mean \pm SE values of serum total cholesterol level (mg/dl).

The results in table (3) indicate that serum total cholesterol level have significant decrease in negative control (G1) when compared with positive control (G2). The mean and the standard deviation values were $87.83 \pm 1.4(\mathrm{mg} / \mathrm{dl})$ in negative control (G1) compared with $111.50 \pm 2.8$ (mg/dl) in positive control (G2).

The groups of broccoli $(2.5 \%$ and $5 \%)$ are G3 and G4 (99.41土 1.5 and $92.66 \pm 2.1 \mathrm{mg} / \mathrm{dl})$ respectively. In $\mathrm{G3}(2.5 \%$ broccoli) there is significant difference in the mean values of serum total cholesterol when compared with negative control G1 $(87.83 \pm 1.4 \mathrm{mg} / \mathrm{dl})$ but there is no significant difference in the mean values of serum total cholesterol in G4 (5\% broccoli) when compared with negative control (G1). On the other hand these groups (G3 and G4) have significant differences in the mean values of serum total cholesterol when compared with positive control G2 $(111.50 \pm \mathbf{2 . 8} \mathbf{m g} / \mathbf{d l})$. Also there is no significant difference among these groups (G3 and G4).

Triglycerides (TG): 
مجلة كلية التربية بالإسماعيلية - العدد الثامن والثلاثون - مايو Y. V

Table (3) illustrate the mean \pm SD values of serum triglycerides level $(\mathrm{mg} / \mathrm{dl})$.The results in table (3) indicate that serum triglycerides level have significant decrease in negative control G1, (42.16 \pm 1.9 $\mathrm{mg} / \mathrm{dl}$ ) when compared with positive control G2, $(63.33 \pm 3.1 \mathrm{mg} / \mathrm{dl})$. The groups of broccoli $2.5 \%$ is $\mathbf{G 3}(54.50 \pm 3.3)$ have significant difference in the mean values of serum triglycerides when compared with negative control G1, (42.16 $\pm 1.9 \mathrm{mg} / \mathrm{dl})$. But in G4 (5\% broccoli) there is no significant difference in the mean values of serum triglycerides (G4: 49.33 \pm 1.2 ) when compared with negative control G1 $(42.16 \pm 1.9 \mathrm{mg} / \mathrm{dl})$, But these groups (G3 and G4) have significant differences in the mean values of serum triglycerides when compared with positive control G2, $(63.33 \pm 3.1 \mathrm{mg} / \mathrm{dl})$. There were no significant differences in the mean values of serum triglycerides among these groups (G3 and G4).

High density lipoprotein cholesterol (HDL-C):

Table (3) illustrate the mean \pm SE values of serum high density lipoprotein cholesterol (HDL-C) level (mg/dl). Table (3) demonstrates that the mean values of serum (HDL-C) level have significant increase in negative control (G1) when compared with positive control (G2). The mean and the standard deviation values were $47.66 \pm 1.8(\mathrm{mg} / \mathrm{dl})$ in negative control (G1) compared with $35.66 \pm 1.08$ (mg/dl) in positive control (G2).

The groups of broccoli $2.5 \%$ is $\mathbf{G 3}(37.16 \pm 2.2)$ have significant difference in the mean values of serum (HDL-C) level when compared with negative control G1, (47.66 $\pm 1.8 \mathrm{mg} / \mathrm{dl})$. But in G4 (5\% broccoli) there is no significant difference in the mean values of serum (HDL-C) level (G4: 41.66 \pm 3.08 ) when compared with negative control. But these groups (G3 and G4) have no significant differences in the mean values of serum (HDL-C) level when compared with positive control G2, $(35.66 \pm 1.08 \mathrm{mg} / \mathrm{dl})$. There were no significant differences in the mean values of serum (HDL-C) level among these groups (G3 and G4). Very low density lipoprotein cholesterol (VLDL-C): Table (3) illustrate the mean \pm SE values of serum very low density lipoprotein cholesterol (VLDL-C) level ( $\mathrm{mg} / \mathrm{dl})$. The results in table (3) indicate that the mean values of serum (VLDL-C) level have significant decrease in negative control G1, $(7.6 \pm 1.66 \mathrm{mg} / \mathrm{dl})$ when compared with positive control G2, $(12.8 \pm 1.87 \mathrm{mg} / \mathrm{dl})$. The groups of broccoli $2.5 \%$ is $G 3(10.90 \pm 0.67)$ have significant difference in the mean values of serum (VLDL-C) level when compared with negative 
control G1, $(8.43 \pm 0.39 \mathrm{mg} / \mathrm{dl})$. But in $\mathrm{G} 4(5 \%$ broccoli) there is no significant difference in the mean values of serum (VLDL-C) level (G4: 9.86 \pm 0.25) when compared with negative control. But these groups (G3 and G4) have significant differences in the mean values of serum (VLDL-C) level when compared with positive control G2, (12.66 \pm 0.62 $\mathrm{mg} / \mathrm{dl})$. There were no significant differences in the mean values of serum (VLDL-C) level among these groups (G3 and G4).

Low density lipoprotein cholesterol (LDL-C):

Table (3) illustrate the mean $\pm \mathrm{SE}$ values of serum low density lipoprotein cholesterol (LDL-C) level (mg/dl).The results in table (3) indicate that the mean values of serum LDL-C level have highly significant decrease in negative control (G1) when compared with positive control (G2). The mean and the standard deviation values were $31.73 \pm 2.13 \mathrm{mg} / \mathrm{dl}$ in negative control (G1) compared with $63.17 \pm 2.41$ $\mathrm{mg} / \mathrm{dl}$ in positive control (G2).

The groups of broccoli $2.5 \%$ is $G 3(51.35 \pm 2.28)$ have significant difference in the mean values of serum LDL-C level when compared with negative control G1, (31.73 $\pm 2.13 \mathrm{mg} / \mathrm{dl})$. But in G4 (5\% broccoli) there is no significant difference in the mean values of serum LDL-C level (G4: 41.13 \pm 3.35) when compared with negative control G1. On other hand group $\mathbf{G 3}$ have no significant differences in the mean values of serum LDL-C level when compared with positive control G2, (63.17 $\pm 2.41 \mathrm{mg} / \mathrm{dl}), \mathbf{G} 4$ have significant differences in the mean values of serum LDL-C level when compared with positive control G2. There were no significant differences in the mean values of serum LDL-C level among these groups (G3 and G4).

From all of the previous results of lipid profile, the present study observed that cabbage, red cabbage and broccoli enhanced the lipid profile in blood serum of rats in the all groups, and the best results showed in the high levels of all of these vegetables.

The results in the current study are in agreement with Pinheiro et al., (2011) and Asadujjaman et al., (2011), who found that rats were injection of STZ had significant increase in total cholesterol, triglycerides and LDL-C also lower HDL-C levels. Also Khan et al., (1995) reported that the common lipid abnormalities in diabetes are hypertriglyceridemia and hypercholesterolemia LDL- cholesterol levels in hypercholesterolemic subjects.

The results also are similar to Suido et al., (2003) who reported that The broccoli and cabbage mixture showed cholesterol lowering effects in hypercholesterolemic rats, Also The HDL-C ratio was 


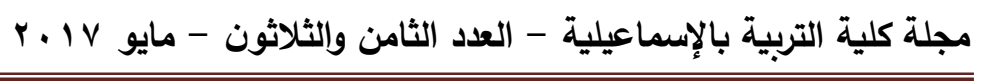

significantly higher than those in the control group, raising a possibility that daily consumption of these vegetables may be useful in lowering serum TC, TG, LDL-C and VLDL-C levels in hypercholesterolemic patients.

The results also in harmony with Bahadoran et al., (2012) and Lee et al., (2009) who showed that broccoli significantly decreased serum triglycerides and LDL -C ratio in type 2 diabetic patients, Also HDL-C concentration was significantly higher when compared with non treated group Also, Asadujjaman et al., (2011), reported that Brassica oleracea fraction reduce blood lipid level significantly in diabetic rats.

\section{Table (3): Effect of experimental diets on lipid profile:}

\begin{tabular}{|c|c|c|c|c|c|}
\hline Rarame & $\begin{array}{c}\text { TOTAL } \\
\text { Cholestero } \\
1\end{array}$ & TG & HDL & VLDL & LDL \\
\hline Groups & \multicolumn{5}{|c|}{$\mathrm{mg} / \mathrm{dl}$} \\
\hline $\begin{array}{l}\text { control } \\
\text { negative }\end{array}$ & $87.83 \pm 1.4^{d}$ & $42.16 \pm 1.9^{d}$ & $47.66 \pm 1.8^{b}$ & $8.43 \pm 0.39^{d}$ & $\begin{array}{l}31.74 \\
\pm 2.1\end{array}$ \\
\hline $\begin{array}{l}\text { control } \\
\text { positive }\end{array}$ & $\begin{array}{c}111.50 \pm 2.8 \\
\mathrm{a}\end{array}$ & $63.33 \pm 3.1^{a}$ & $35.66 \pm 1.08^{d}$ & $\begin{array}{c}12.66 \pm 0.62 \\
a\end{array}$ & $\begin{array}{c}63.17 \pm \\
2.4\end{array}$ \\
\hline $2.5 \%$ broccoli & $99.41 \pm 1.5^{b}$ & $\begin{array}{c}54.50 \pm 3.3 \\
\text { bc }\end{array}$ & $37.16 \pm 2.2^{\mathrm{cd}}$ & $\begin{array}{c}10.90 \pm \\
0.67^{\mathrm{bc}}\end{array}$ & $\begin{array}{c}49.69 \pm \\
2.28\end{array}$ \\
\hline $5 \%$ broccoli . & $\begin{array}{c}92.66 \pm 2.1 \\
\text { bcd }\end{array}$ & $\begin{array}{c}49.33 \pm 1.2 \\
\text { cd }\end{array}$ & $\begin{array}{c}41.66 \\
\pm 3.08^{\text {bcd }}\end{array}$ & $9.86 \pm 0.25^{c d}$ & $\begin{array}{l}41.13 \\
\pm 3.35\end{array}$ \\
\hline
\end{tabular}

- Values are expressed as means $\pm \mathrm{SE}$.

- Means with the different letter superscripts in the same column denote significance at $P<0.05$

\section{\&-Effect of experimental diets on kidney function:}

Serum uric acid:

Table (4) illustrate the mean $+\mathrm{SE}$ values of serum uric acid ( $\mathrm{mg} / \mathrm{dl})$. The data in table (4) showed that the mean values of serum uric acid level have no significant differences in negative control G1, $(2.99 \pm 0.13 \mathrm{mg} / \mathrm{dl})$ when compared with positive control G2, $(3.50 \pm$ 
$0.30 \mathrm{mg} / \mathrm{dl}$ ), the all groups G3 and G4 also have no significant differences when compared with negative control (G1), and have no significant differences when compared with positive control (G2). They also have no significant differences among themselves.

Serum urea:

Table (4) illustrate the mean $+\mathrm{SE}$ values of serum urea $(\mathrm{mg} / \mathrm{dl})$.The data in table (4) showed that there were significant differences in serum urea level in negative control G1, $(15.25 \pm 0.50$ $\mathrm{mg} / \mathrm{dl})$ when compared with positive control G2, $(18.75 \pm 0.83 \mathrm{mg} / \mathrm{dl})$. The groups of broccoli ( $2.5 \%$ and $5 \%)$ are $\mathrm{G3}$ and $\mathrm{G} 4$ registered $17.61 \pm 0.83$ and $17.50 \pm 0.68 \mathrm{mg} / \mathrm{dl}$, respectively have significant differences in the mean values of serum urea level when compared with negative control $\mathrm{G} 1,(\mathbf{1 5 . 2 5} \pm \mathbf{0 . 5 0} \mathbf{~ m g} / \mathrm{dl})$. But these groups (G3 and G4) have no significant differences in the mean values of serum urea level when compared with positive control G2, $(18.75 \pm 0.83 \mathbf{~ m g} / \mathbf{d l})$. There were no significant differences in the mean values of serum urea level among these groups (G3 and G4).

Serum creatinine:

Table (4) illustrate the mean $+\mathrm{SE}$ values of serum creatinine (mg/dl). The data in table (4) showed that there were no significant differences in serum creatinine in negative control $\mathrm{G1},(0.90 \pm 0.0212$ $\mathrm{mg} / \mathrm{dl})$ when compared with positive control G2, $(0.98 \pm 0.0476 \mathbf{~ m g} / \mathbf{d l})$. The groups of broccoli ( $2.5 \%$ and $5 \%)$ are $\mathrm{G3}$ and $\mathrm{G} 4$ registered $0.91 \pm 0.063$ and $0.84 \pm 0.0159 \mathrm{mg} / \mathrm{dl}$, respectively have no significant differences in the mean values of serum creatinine when compared with negative control G1, $(0.90 \pm \mathbf{0 . 0 2 1 2} \mathbf{~ m g} / \mathbf{d l})$. Also G3 have no significant difference in the mean values of serum creatinine when compared with positive control G2, $(0.98 \pm 0.0476 \mathrm{mg} / \mathrm{dl})$. But there is significant difference in the mean values of serum creatinine for $\mathbf{G 4}$ when compared with positive control. There were no significant differences in the mean values of serum creatinine among these groups (G3 and G4). Kataya and Hamza (2008) showed that in diabetic rats, elevation in serum urea and serum creatinine concentrations. 


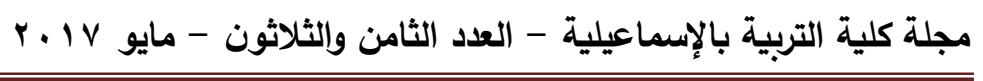

Table (4): Effect of experimental diets on kidney function

\begin{tabular}{|l|c|c|c|}
\hline \multirow{2}{*}{ Parameters } & URICACID & UREA & CREATIN \\
\cline { 2 - 4 } & \multicolumn{3}{|c|}{$\mathrm{mg} / \mathrm{dl}$} \\
\hline control negative & $2.99 \pm 0.13^{\mathrm{a}}$ & $15.25 \pm 0.50^{\mathrm{cd}}$ & $\mathbf{0 . 9 0} \pm 0.0212^{\text {abc }}$ \\
\hline control positive & $3.50 \pm 0.30^{\mathrm{a}}$ & $18.75 \pm 0.83^{\mathrm{a}}$ & $\mathbf{0 . 9 8} \pm 0.0476^{\mathrm{a}}$ \\
\hline $2.5 \%$ broccoli . & & & \\
\hline $\mathbf{5 \%}$ broccoli. & $2.96 \pm 0.28^{\mathrm{a}}$ & $17.61 \pm 0.83^{\mathrm{ab}}$ & $\mathbf{0 . 9 1} \pm 0.036^{\mathrm{abc}}$ \\
\hline
\end{tabular}

- Values are expressed as means $\pm \mathrm{SE}$.

- Means with the different letter superscripts in the same column denote significance at $\mathbf{P}<0.05$

\section{--Effect of experimental diets on liver function:}

Serum ALT (SGPT):

Table (5) demonstrate the mean and + SE values of serum ALT

$(\mathrm{mg} / \mathrm{dl})$. The data in table (5) indicate that the mean values of serum ALT level have significant decrease in negative control (G1) when compared with positive control (G2). The mean and the standard deviation values were $21.31 \pm \mathbf{0 . 8 0} \mathbf{~ m g} / \mathbf{d l}$ in negative control (G1) compared with $26.01 \pm 0.60 \mathrm{mg} / \mathrm{dl}$ in positive control (G2). The groups of broccoli (2.5\% and 5\%) are G3 and G4 registered $19.48 \pm 0.59$ and $22.50 \pm 1.7 \mathrm{mg} / \mathrm{dl}$, respectively have no significant differences in the mean values of serum ALT level when compared with negative control G1, (21.31 $\pm \mathbf{0 . 8 0} \mathrm{mg} / \mathrm{dl})$. But G3 have significant difference in the mean values of serum ALT level when compared with positive control $\mathrm{G} 2,(26.01 \pm \mathbf{0 . 6 0} \mathbf{~ m g} / \mathrm{dl})$. On the other hand G4 have no significant difference in the mean values of serum ALT level when compared with positive control G2 There were no significant differences in the mean values of serum ALT level among these groups (G3 and G4).

Serum AST (SGOT):

Table (5) demonstrate the mean + SE values of serum AST $(\mathrm{mg} / \mathrm{dl})$. The data in table (5) indicate that the mean values of serum 
AST level have significant decrease in negative control (G1) when compared with positive control (G2). The mean and the standard deviation values were $92.00 \pm 2.4 \mathrm{mg} / \mathrm{dl}$ in negative control (G1) compared with $103.33 \pm \mathbf{2 . 0} \mathbf{~ m g} / \mathrm{dl}$ in positive control (G2). The groups of broccoli $(2.5 \%$ and $5 \%)$ are $\mathrm{G} 3$ and $\mathrm{G} 4$ registered 100.66 \pm 4.5 and $96.33 \pm 2.8 \mathrm{mg} / \mathrm{dl}$, respectively have no significant differences in the mean values of serum AST level when compared with negative control G1, (92.00 $\pm \mathbf{2 . 4} \mathbf{~ m g} / \mathbf{d l})$. Also these groups (G3 and G4) have no significant differences in the mean values of serum AST level when compared with positive control G2, $(103.33 \pm 2.0 \mathrm{mg} / \mathrm{dl})$. There were no significant differences in the mean values of serum AST level among these groups (G3 and G4).

These results in harmony with Asadujjaman et al., (2011) and Scott et al., (1984) who found that there is increase in the activities of ALT and AST is found in diabetic rats. Asadujjaman et al., (2011) and Al-Howiriny (2008) reported that Brassica oleracea fraction reduce blood lipid level significantly in diabetic rats. Aml et al., (2010) cleared that broccoli and red cabbage extracts caused significant decrease in serum levels of ALT and AST in rats.

Table (5): Effect of experimental diets on liver function:

\begin{tabular}{|c|c|c|}
\hline \multirow{2}{*}{ Parameters } & $\begin{array}{c}\text { GPT } \\
\text { GLT }\end{array}$ & $\begin{array}{c}\text { GOT } \\
\text { AST }\end{array}$ \\
\cline { 2 - 3 } & \multicolumn{2}{|c|}{$\mu / \mathrm{L}$} \\
\hline control negative & $21.31 \pm 0.80$ bc & $92.00 \pm 2.4^{\text {bcd }}$ \\
\hline control positive & $26.01 \pm 0.60^{\mathrm{a}}$ & $103.33 \pm 2.0^{\mathrm{a}}$ \\
\hline $2.5 \%$ broccoli & $19.48 \pm 0.59 \mathrm{bcd}$ & $100.66 \pm 4.5$ ab \\
\hline $5 \%$ broccoli & $22.50 \pm 1.7^{\text {abc }}$ & $96.33 \pm 2.8$ abc \\
\hline
\end{tabular}

- Values are expressed as means $\pm \mathrm{SE}$.

- Means with the different letter superscripts in the same column denote significance at $\mathbf{P}<\mathbf{0 . 0 5}$.

References:

- Al-Howiriny T. (2008): Evaluation of Hepatoprotective Activity of Broccoli 'Brassica oleracea' in Rats. Hungarian Medical Journal, 2(1): 145-156. 


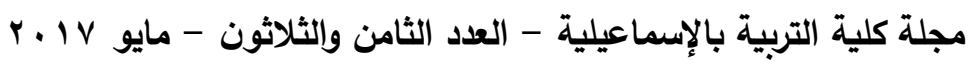

- Aml F. M. Morsy*a, Hodaa S. Ibrahima and M. A. Shalaby. (2010): Protective Effect of Broccoli and Red Cabbage Against Hepatocellular Carcinoma Induced by $\mathrm{N}$ - Nitrosodiethylamine in Rats. J.Ameri. Sci.,: 6(12).

- Asadujjaman M, Hossain MS, Khan MR, Anisuzzaman AS, Ahmed $M$ and Islam A. (2011): Antihyperglycemic and glycogenesis effects of different fractions of brassica oleracea in alloxan induced diabetic rats. Int.J.Pharmaceutical Sci. Research, 2(6):1436-1442.

- Bacchetti T, Tullii D, Masciangelo S, Gesuita R, Skrami E, Brugè F, Silvestri S, Orlando P, Tiano L, Ferretti G.(2014): Effect of black and red cabbage on plasma carotenoid levels, lipid profile and oxidized low density lipoprotein. J. Functional Foods, Volume 8, May 2014, Pages 128-137.

- Bahadoran Z, Mirmiran P, Hosseinpanah F, Rajab A, Asghari G, and Azizi F. (2012): Broccoli sprouts powder could improve serum triglyceride and oxidized LDL/LDL-cholesterol ratio in type 2 diabetic patients: a randomized double-blind placebocontrolled clinical trial. Int.J.Pharmaceutical Sci. Research, 2(7):1662-1668.

- Bai Y, Cui W, Xin Y, Miao X, Barati M, Zhang C, Chen Q, Tan Y, Cui T, Zheng Y, Cai L, (2013): Prevention by sulforaphane of diabetic cardiomyopathy is associated with up-regulation of Nrf2 expression and transcription activation J. of Molecular and Cellular Cardiology 57 82-95

- Burtis CA and Ashwood ER (1999): Tietz Textbook of Clinical Chemistry. 3rd ed. Philadelphia: W.B. Saunders, 2184.

- Burtis CA and Ashwood ER (2001): Tietz Fundamentals of Clinical Chemistry, 5th Ed., Philadelphia, Pa: W.B. Saunders.

- Chapman DG, Castillo R and Campbell JA. (1959): Evaluation of proteins in foods. Canad J. Biochem. Biophysics, 37: 679-683.

- Cho EJ, Lee YA, Yoo HH, Yokozawa T. (2006): "Protective Effects of Broccoli (Brassica oleracea) against Oxidative Damage in Vitro and in Vivo". Journal of Nutritional Science and Vitaminology, 52(6):437-444.

- Fossati P and Prencipe L. (1982): Serum triglycerides determined colon- metrically with an enzyme that produceshydrogen peroxide. Clin. Chem., 28:2077-80. 
- Fossati P, Prencipe L and Berti G. (1980): Use of 3,5-dichloro-2hydroxybenzenesulfonic acid/4-amino-phenazone chromogenic system in direct enzymic assay of uric acid in serum and urine. Clinical Chemistry, 26: 227-231.

- Friadwald WT, Levy R I and Fredrickson DS. (1972): Estimation of the concentration of low density lipoprotein; separation by three different methods. Clin. Chem., 18:499-502.

- Hegested DM. (1941): Saltmixture. J. Biochem., 138:450-459.

- IFCC, International Federation of Clinical Chemistry (1980): Clin. Chim. Biochem.; 105:145F-172F.

- Jaffé, M. (1986): ueber den Niederschlag, welchen Pikrinsäure in normalem Harn erzeugt und über eine neue Reaktion des Kreatinins. Z Physiol. Chem., 10:391-400.

- Kanapka JJ. (1983): Nutrition. In: The Mouse in Biomedical Research, Normative Biology, Immunology and Husbandry (Foster, H.L; Small, J.D. and Fox, J.G.), Academic Press, New York, NY, Vol. III, 52-67.

- Kataya HA and Hamza AA. (2008): Red Cabbage (Brassica oleracea) Ameliorates Diabetic Nephropathy in Rats. Evid Based Complement Alternat Med., 5(3): 281-287.

- Khan BA, Abraham A, and Leelamma S (1995): Hypoglycemic action of Murraya koenigii (curry leaf), Brassica juncea (mustard); mechanism of action. India J. Biochem. and Biophysics, 32:106-108.

- Lee J, Shin H, Lee Y, Kim A. and Lee M. (2009): Effect of broccoli sprouts on cholesterol-lowering and anti-obesity effects in rats fed high fat diet. J Korean Soc Food Sci Nutr., 38(3):30918.

- Mc-Gowan MW, Artiss JD, Strandbergh DR and Zak B. (1983): Enzymatic colorimetrie method for determination of triglycerides. Clinical Chemistry, 29: 538-539.

- Pinheiro LS, Melo AD, Andreazzi AE, Caires Júnior LC, Costa MB, Garcia RM. (2011): Protocol of Insulin Therapy For Streptozotocin-Diabetic Rats Based on a Study of Food Ingestion and Glycemic Variation. Published in the Scandinavian Journal of Laboratory Animal Science - an international journal of laboratory animal science. 


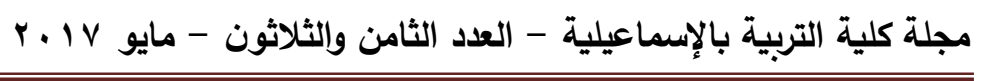

- Reeves P, Nielsen F and Fahmy G. (1993): Reported of the American Institute of Nutrition; committee on the reformulation of the AIN76, A rodent diet. J. Nutrition, 123:1939-51.

- Schultz A. (1984): Uric acid. In: Kaplan, A. (Ed.), Clin. Chem., The C.V. Mosby Co. St Louis. Toronto. Princeton, 418: 12611266.

- Scott FW, Trick KD, Lee LP, Hynie I, Heick HM and Nera EA (1984): Serum enzymes in the BB rat before and after onset of the overt diabetic syndrome. Clin. Biochem., 17(4): 270-275.

- Suido H, Takeuchi A, Makino T Tanaka T. (2003): Serum cholesterol-lowering effects of a broccoli and cabbage mixture in rats Sunstar Inc., R\&D Center; Osaka University Medical School, Japan.

- Temple C, Clark P and Hales N. (1992): Measurement of insulin secretion in type 2 diabetes: problems and pitfalls. Diabetic medicine, 9: 503-512.

- Trinder P and Ann A. (1969): Colorimetric determination of total cholesterol. Clin. Biochem., 6:24-34.

- Villanova PA. (1994): National Committee for Clinical Laboratory Standards. Approved Guideline, NCCLS publication C28-A.

- Wien, H and Wurr, D. (1997): Cauliflower, Broccoli, Cabbage and Brussels Sprouts. The Physiol. Vege. Crops: 511-544

- Yanardag R, Bolkent S, Karabulut-Bulan O, and Tunali S. (2003): Effects of vanadyl sulfate on kidney in experimental diabetes. Biol Trace Elem Res., 95:73-85. 
تأثير البروكلى على الحالة الذذائية للفئران المصابة بمرض السكر

\section{الملخص العربحى}

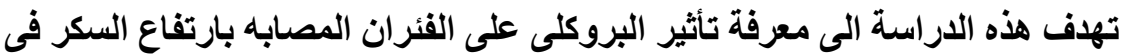

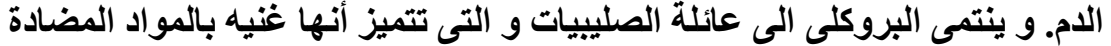

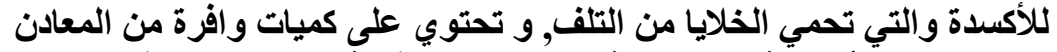

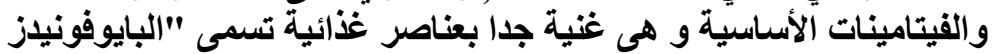

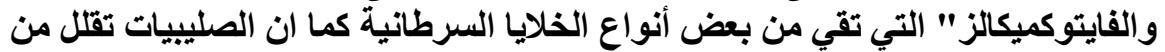

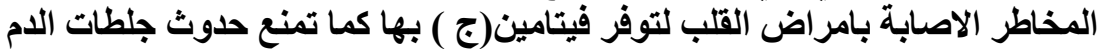

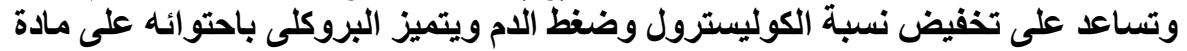

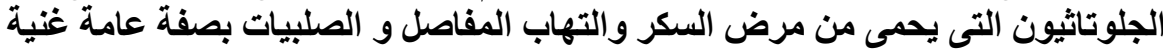

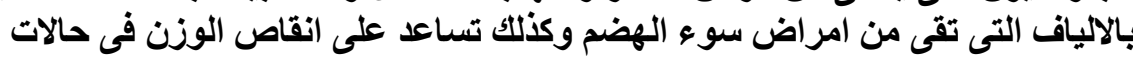

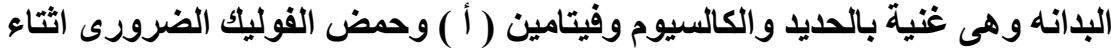

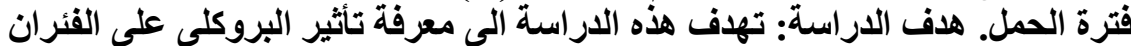

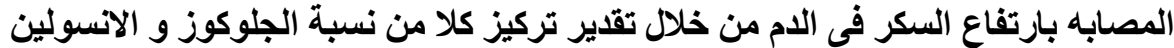

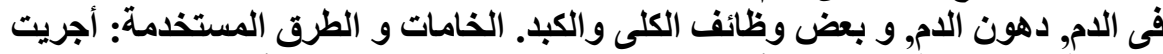

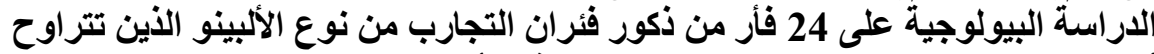

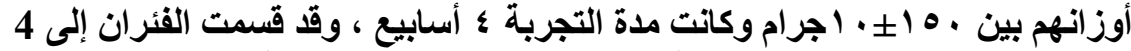

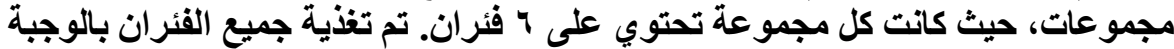

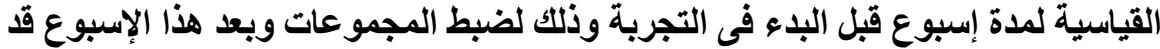

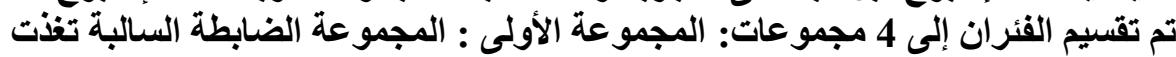

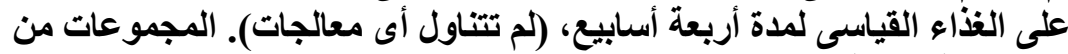

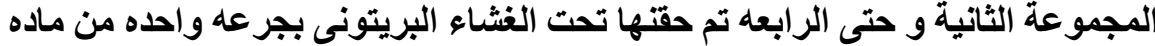

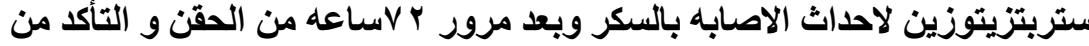

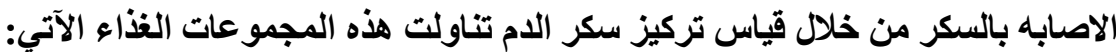

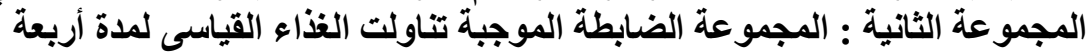

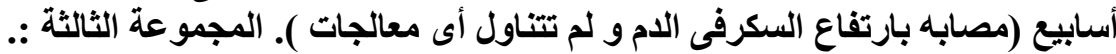

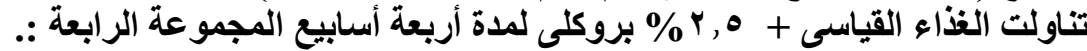

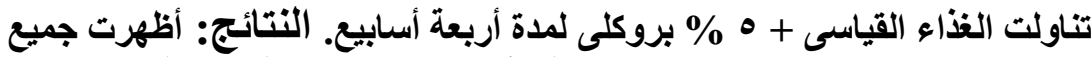

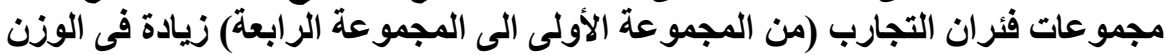

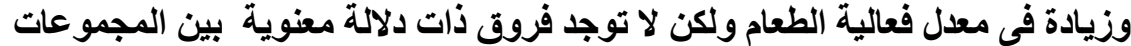

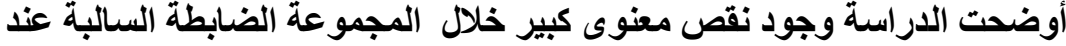

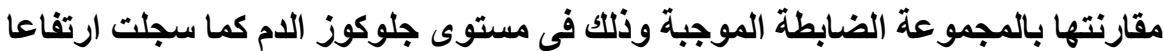

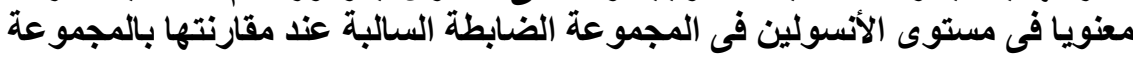

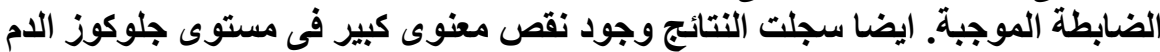

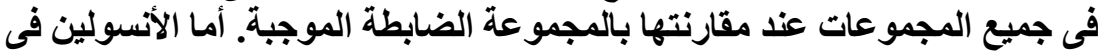

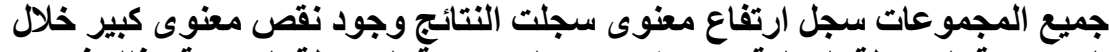

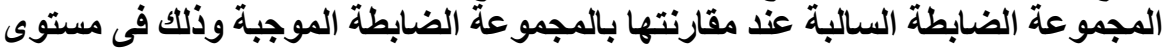

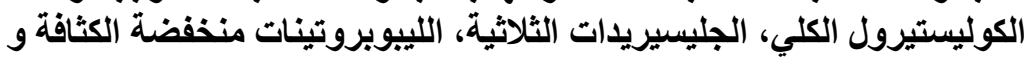




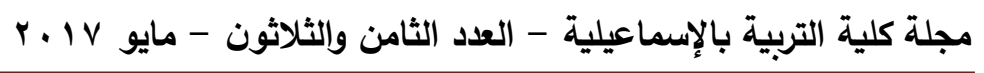

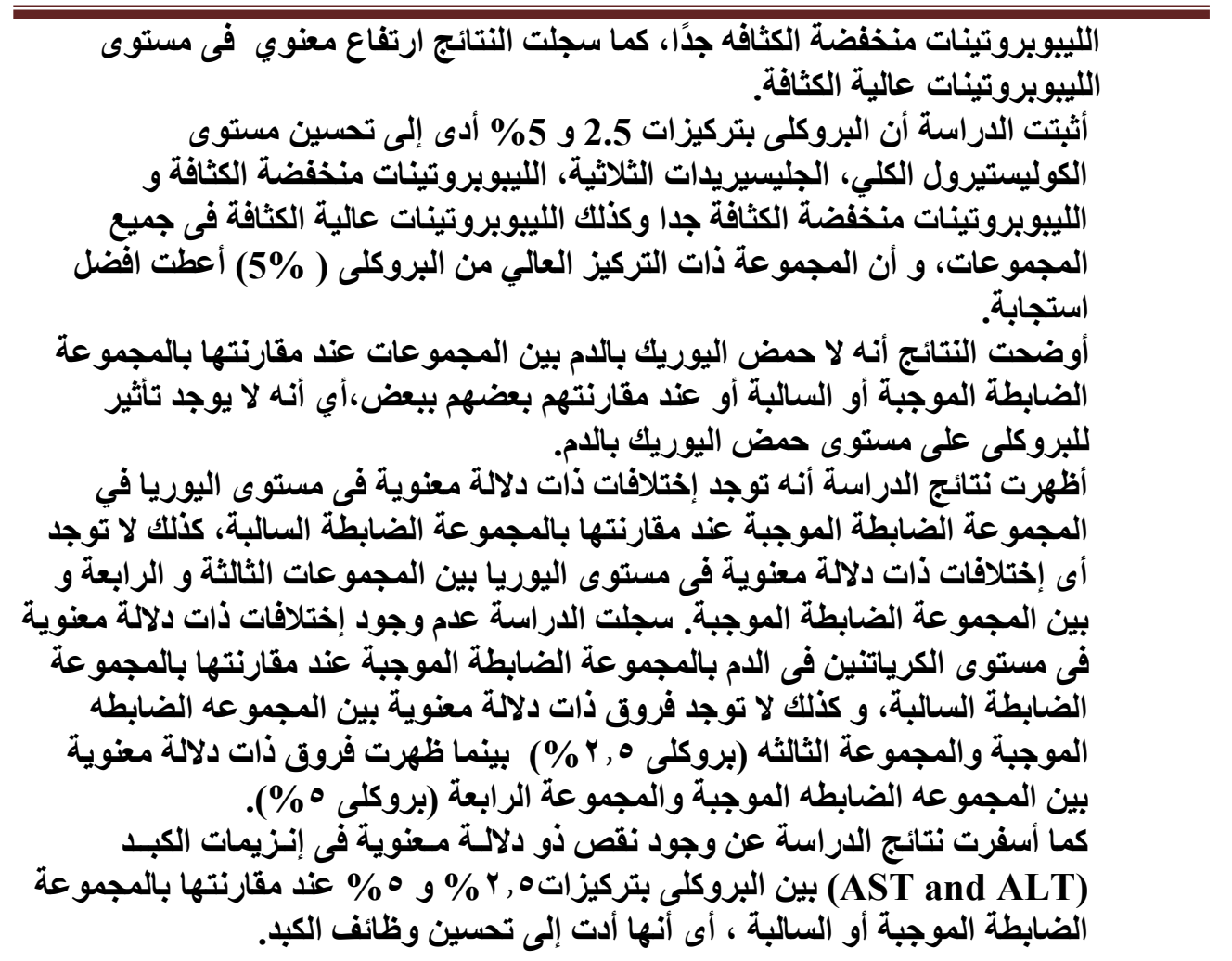

